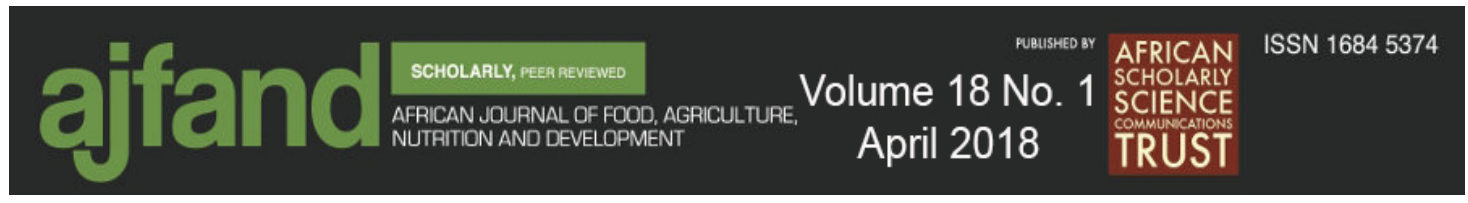

\title{
CAN BLENDED FLOUR RECIPES MADE OF LOCALLY AVAILABLE AND CHEAP INGREDIENTS BE USED FOR ADEQUATE COMPLEMENTARY FEEDING OF INFANTS IN RURAL SETTINGS IN BURKINA FASO?
}

\author{
Elysée SY ${ }^{*}$, Aminata $C^{2}$, and P Donnen ${ }^{3}$
}

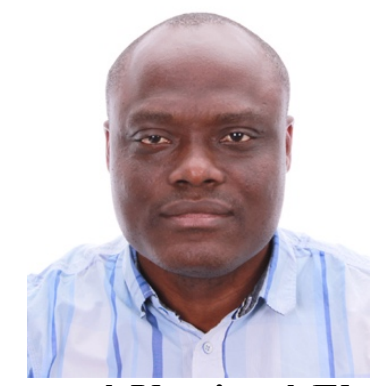

Somassè Yassinmè Elysée

*Corresponding author email : ysomasse@ulb.ac.be

${ }^{1}$ Medical Doctor, Master of Science in Public Health and Teaching Assistant at the school of public health of Université Libre de Bruxelles, Belgium. Address: Ecole de santé publique, Campus Erasme CP 594, Route de Lennik 808, 1070 Brussels

${ }^{2}$ Master of Nutrition, Field Coordinator at International Baby Food Action Network in Burkina-Faso. Address: 01 BP 3881, Ouaga1, Ouagadougou, Burkina-Faso

${ }^{3}$ Medical Doctor and phD in Public Health, Professor at the school of public health of Université Libre de Bruxelles, Belgium. Address : Ecole de santé publique, Campus Erasme CP 594, Route de Lennik 808, 1070 Brussels 


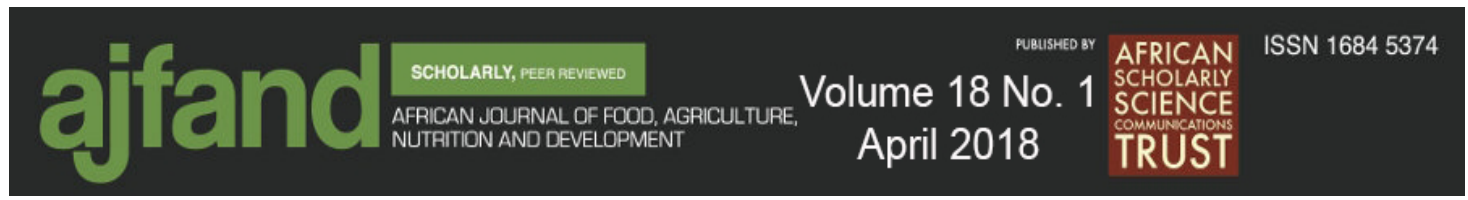

\begin{abstract}
Malnutrition, including deficiencies in micronutrients, stunting, wasting and underweight, is a public health concern among children under-five years in developing countries. Inadequate complementary feeding consisting of giving monotonous, lowenergy and low-micronutrients dense cereal porridge is a common cause of malnutrition. The objective of this study was to identify and to assess the nutritional quality and the energy content of infant and young child homemade blended flours in the rural settings of Southwest Burkina Faso in order to promote blended flour recipes whose composition would be suitable as complementary foods for breastfed infants and young children in Burkina Faso. Cereal-based local blended flours were recorded through a survey in 10 villages. Five (5) recipes that contained at least one protein source (like beans or animal product) were selected for improvement and nutrient content analysis. Sensory evaluation of the porridge made from the blended flours was conducted using the infants, young children and mothers. The feasibility (cost and workload involved) have been also assessed among mothers. The energy content of analyzed blended flours ranged from 430 to $454 \mathrm{kcal} / 100 \mathrm{~g}$, with 11.5 to $14 \mathrm{~g}$ of protein. Flours were well accepted by children. The time required to prepare a blended flour recipe was estimated at 2 hours per week for one child, and all women interviewed found it acceptable. Flours recipes that used sugar were found costly and unaffordable by 40 to $50 \%$ of women according to the blended flour. Taking into account the cost, two blended flours recipes were preferred: Flour recipe A: Pearl millet (48\%), beans (7\%), peanuts (23\%), sumbala (fermented seed of Parkia biglobosa) (7\%), and monkey bread (15\%). Flour recipe B: Pearl millet (48\%), beans $(7 \%)$, peanuts $(26 \%)$, small fish powder $(4 \%)$, and monkey bread $(15 \%)$. All the five blended flours met the minimum recommended energy density for complementary food of $400 \mathrm{kcal} / 100 \mathrm{~g}$. However, except for vitamin $\mathrm{C}$, the micronutrients contents were insufficient. To address micronutrients deficiencies in this rural setting of Burkina Faso, additional sources of micronutrients should be given to children.
\end{abstract}

Key words: Child nutrition, complementary feeding, local foods, sub-Saharan Africa 


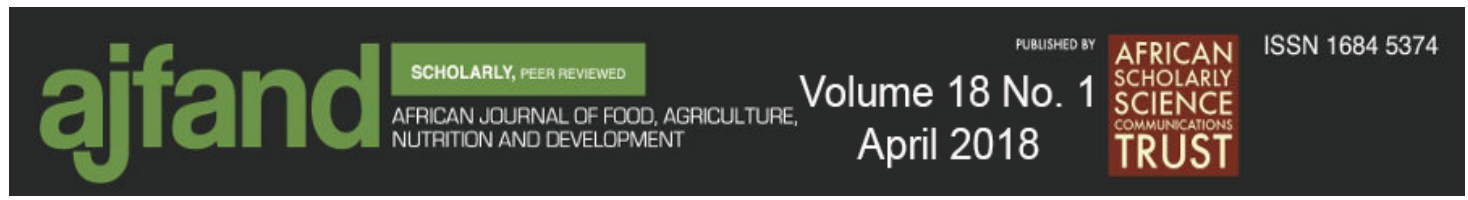

\section{INTRODUCTION}

Malnutrition, including deficiencies in micronutrients, stunting, wasting, and underweight, is a public health concern in developing countries. In 2011, more than $92 \%$ and $96 \%$ of stunted and wasted children under five years, respectively, lived in Africa and Asia [1], and the vast majority of them in sub-Saharan Africa or South-Central Asia [2]. At least one third of under-five deaths worldwide are related to malnutrition [2]. Malnutrition is associated with impaired mental and psychological development in childhood as well as reduced productivity and poor socioeconomic status, increased perinatal complications, and mortality in adulthood [3].

Insufficient supply of protein and energy is one of the direct causes of malnutrition in sub-Saharan countries [4]. This occurs often during complementary feeding period where children make the transition from breast milk to solid foods [2]. Indeed, mothers in rural settings do not know how to combine available cheap local foods to meet nutrients requirements for their children [5]. They give children undiversified complementary foods [6,7] composed mainly of a thin porridge prepared from flour of cereals (sorghum, maize, millet or rice) [7,8] with no or few additional sources of energy or protein. Such diets are very low-energy-dense with little content of protein and micronutrients. Thus, children run a high risk of malnutrition during the weaning period, thus transition from breast milk to solid foods [9].

To improve complementary feeding, many blended flours with high energy content, fortified with minerals and vitamins are sold by small local companies or imported by developing countries. However, the cost of these flours is high and unaffordable for poor families. Moreover, some of these flours are not culturally accepted. To avoid malnutrition for the children from these families, it is necessary that mothers give cheap homemade, energy and micronutrient dense porridge to their children.

In rural settings of the Southwest Region of Burkina-Faso, agricultural crops should allow food self-sufficiency [10]. Nevertheless, the rate of malnutrition is as high as in other parts of the country, due to mothers' ignorance of good nutritional practices, namely healthy foods for adequate child feeding [5].

Hypothesis has been made that some homemade recipes of infant blended flour can fulfill minimum nutrient and energy density to prevent malnutrition. Thus, the objectives of this study were to identify and assess the nutritional quality and the energy content of homemade blended flours in the rural settings of Southwest Burkina Faso in order to select blended flour recipes whose composition would be suitable as complementary foods for breastfed infants and young children in Burkina Faso. 


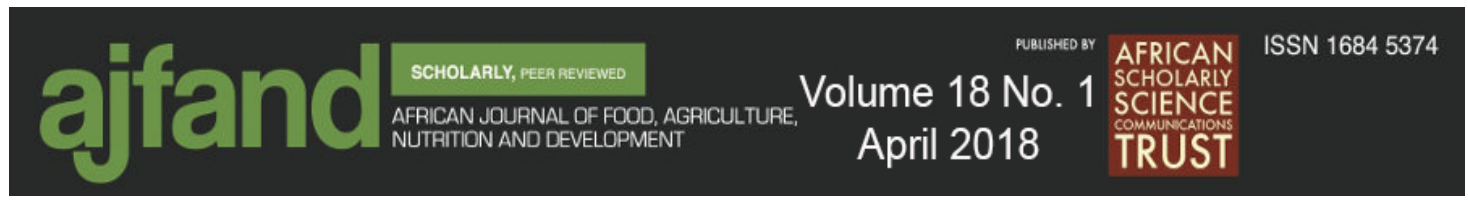

MATERIAL AND METHODS

The following steps were followed for the identification of the different recipes used, sample preparations and analysis.

\section{Identification of recipes}

A survey was conducted to collect local infant and young child cereal-based flour recipes used within the communities. This survey was conducted by two community health workers in 10 villages, randomly selected from two provinces. The community health workers were asked to record every recipe used to make infants blended flour based on cereals, during a public meeting (20 to 30 women) in each village.

The identified blended flours used for infant and young child feeding were classified according to the ingredients used for their production into two groups: blended flours with protein source like beans or fish and blended flours without any protein source (made only from combination of cereals, tubers or roots). The recipes without any protein source were excluded from nutritional evaluation. The remaining five recipes were chosen for evaluation of energy and nutrient content and process improvement.

\section{Processing and composition of selected blended flour recipes}

In 5 villages, two mothers of children aged 6-24 months were chosen by the communities during the meeting which had been convened for the selection of recipes, to prepare the blended flours. These women were not paid for that work, but the ingredients for the recipes were made available by the research team.

The recipes were modified by soaking and toasting the pearl millet and the beans to improve the flour quality. The processing of blended flours is shown in detail in Figure 1. All the ingredients were first sorted to eliminate dirt, damaged grains, foreign grains, noxious seeds, insects, their excreta, and any adhering material [11].

Soaking was done by completely immersing the grains in water at room temperature for 12 hours. The grains were then dried in ambient air for 12 hours before toasting. In a large traditional stove with firewood and a low heat, the ingredients were toasted carefully: grains were continuously mixed in the stove and the process was stopped as soon as the grains became golden to avoid protein damage by "Maillard reaction". Lastly, the ingredients were ground (with a stone mill) and mixed to obtain blended flour. 

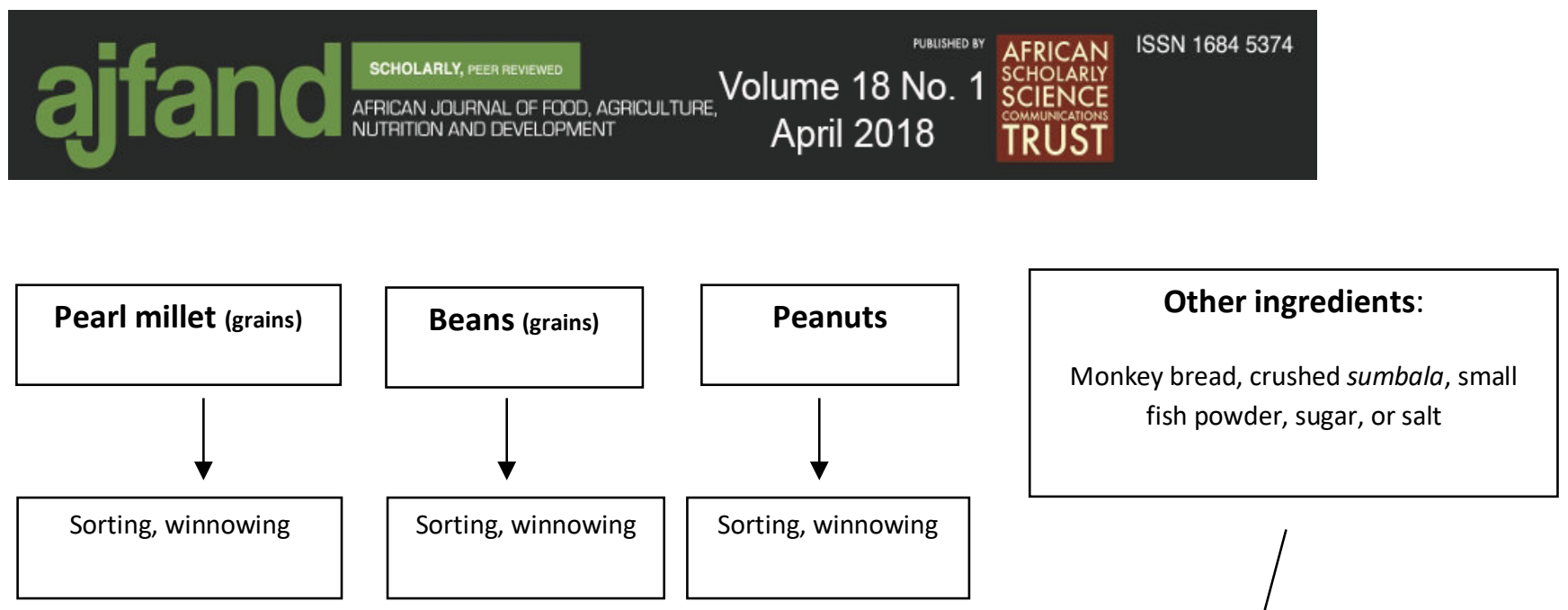

Sorting, winnowing

Sorting, winnowing
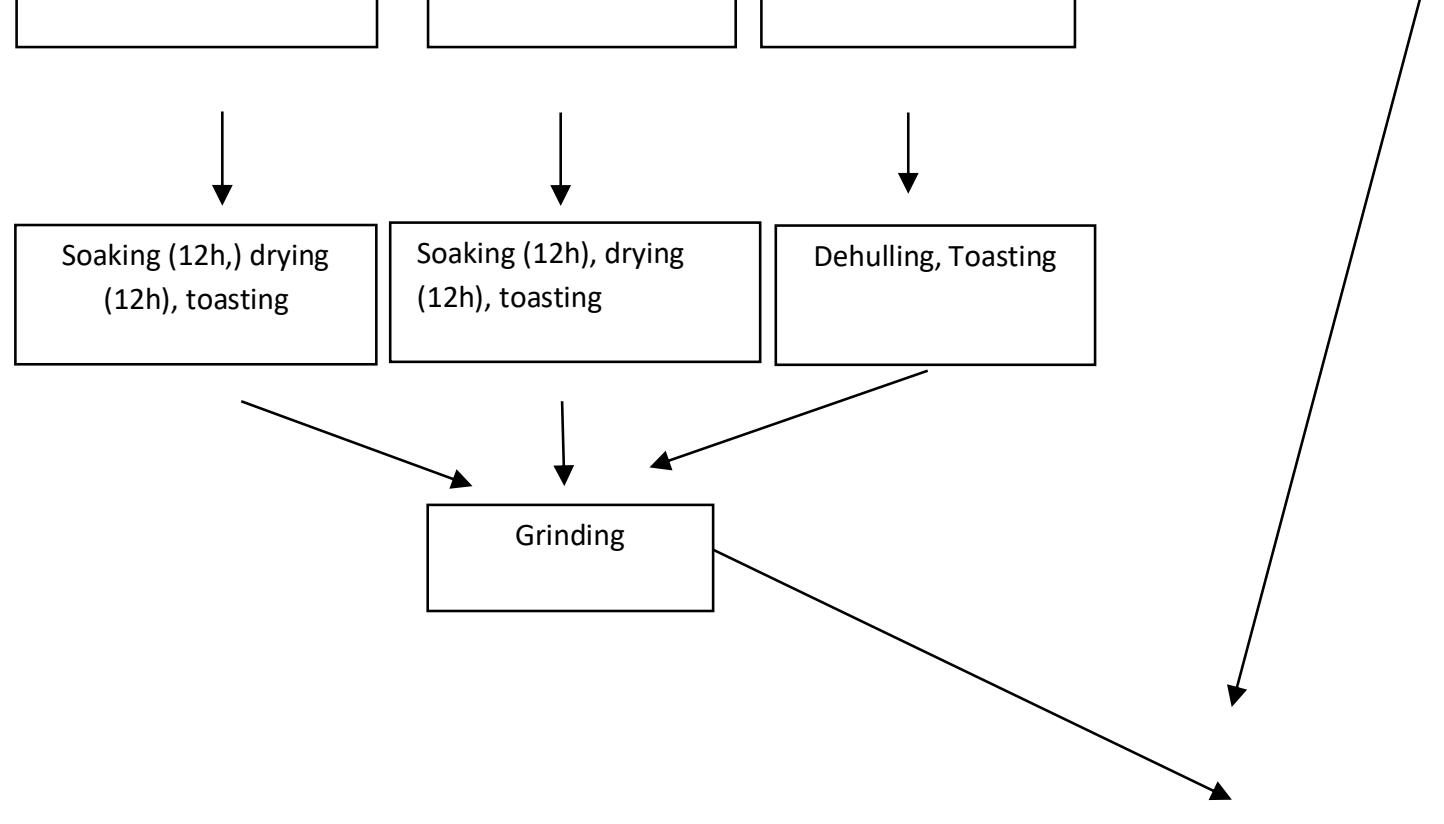

Mixing $\rightarrow$ Blended flour

Figure 1: Processing of the blended flour

Table 1 gives the details of flours with the ingredients used. For all recipes, sumbala (fermented seed of Parkia biglobosa) was bought on the local market. The quantity of each ingredient used for the recipes was determined by measuring the volume of local utensils used.

\section{Nutritional analysis of flours}

Five hundred grams $(500 \mathrm{~g})$ of each type of blended flour were drawn at the time of its production using aseptic material and transported in closed dark sachets. The flours were stored at room temperature and protected from light by keeping them in dark plastic bags (to preserve vitamin A content) for 24 hours maximum, before they were sent to the laboratory for in vitro analysis of nutritional content.

Three laboratories in Ouagadougou (capital of Burkina Faso) carried out the nutritional analysis. The Ouagadougou University laboratory for nutritional analyses named "Centre de Recherche en Sciences Biologiques Alimentaires et Nutritionnelles (CRSBAN)" analyzed the protein, vitamin $\mathrm{C}$, vitamin $\mathrm{E}$, and vitamin $\mathrm{A}$ contents. The national 


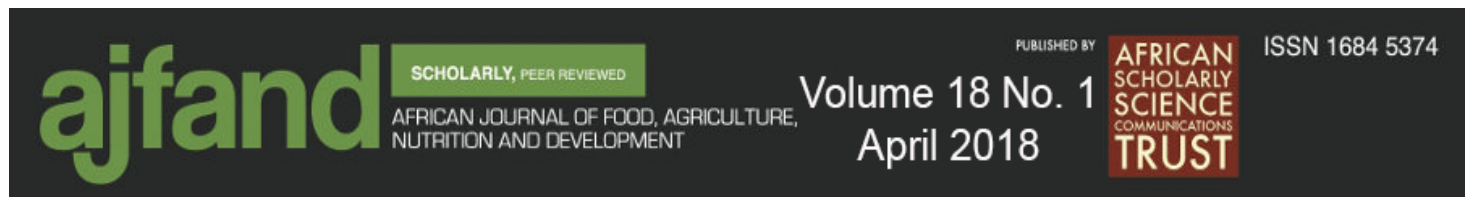

laboratory named "Bureau des Mines et de la Géologie du Burkina (BUMIGEB)" analyzed the dry matter and mineral contents. Lipids content was analyzed by the laboratory of the Ministry of Scientific Research and Innovation named "Institut de Recherche en Sciences Appliquées et Technologies (DTA/IRSAT)".

The methods used for nutritional contents were based on the Association of Official Analytical Chemists (AOAC) methods [12]. The content of carbohydrates was determined by using the 'By Difference Method'.

\section{Carbohydrate $(\%)=100-[$ Moisture $(\%)+$ Protein $(\%)+$ Lipid $(\%)+$ Ash $(\%)]$}

\section{Sensory and Acceptability test}

Assessment of amount of porridge eaten by children

The amount of porridge eaten by children (12-23 months of age) was determined by measuring the remaining porridge from a cup of $200 \mathrm{ml}$. Children were not forced by their mother to eat. The tests were carried out in four villages at 9 am and the mothers were asked to not feed the child during the 4 hours preceding the test.

Each porridge was prepared with $300 \mathrm{~g}$ of blended flour to obtain $3000 \mathrm{ml}$ of porridge with drinking water for the test at the ratio of $10 \mathrm{~g}$ : $100 \mathrm{ml}$, respectively. For the preparation of the porridge, the following process was carried out: the blended flour was slurried in a third part of water at room temperature. The two other third of water was boiled, and then the slurried blended flour was added and mixed for 3-5 minutes to get a thick porridge that could fit in an inclined spoon. For each type of blended flour, the percentage of children (aged 12-23 months) that ate at least $150 \mathrm{ml}$ and $200 \mathrm{ml}$ of the porridge were computed.

\section{Sensory evaluation and feasibility}

The mothers were given a cup of $200 \mathrm{ml}$ of the same porridge eaten by their child. They were asked to give their view on the taste, aroma and the visual aspect of porridge (sensory evaluation). They had three possibilities for each sensory variable evaluated: "liked", "had no opinion" or "did not like".

The feasibility was assessed by the perception of the used ingredients costs, as well as the workload involved (time spent) in flours recipes preparation. Mothers had also three possibilities: "acceptable", "no opinion", "unacceptable".

For each blended flour, the percentage of mothers who liked the sensory characteristics and the percentage of mothers who found acceptable the costs and workload needed for blended flour preparation were computed. A blended flour was considered weakly accepted by mothers when the percentage of favorable evaluations (liked or acceptable) was below $80 \%$ for one of the criteria. 


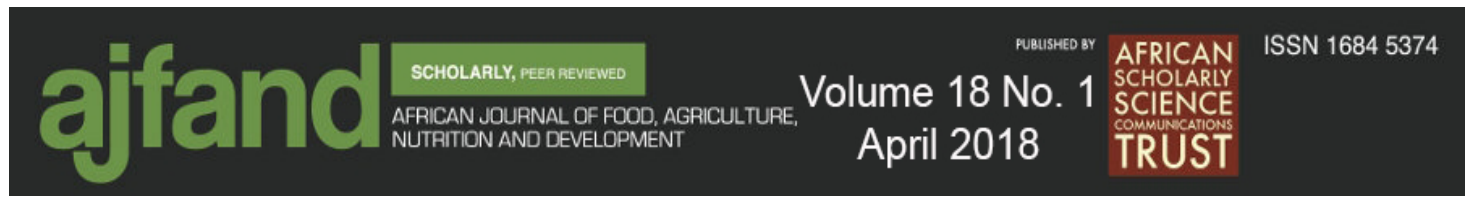

RESULTS

\section{Nutritional content of blended flour}

The nutritional content of the blended flours analyzed are displayed in Table 2 . The energy content ranged from $430 \mathrm{kcal} / 100 \mathrm{~g}$ to $454 \mathrm{kcal} / 100 \mathrm{~g}$, while the protein contents were between $11.5 \mathrm{~g}$ and $14.2 \mathrm{~g}$ per $100 \mathrm{~g}$. The lipid content ranged from $8.8 \mathrm{~g} / 100 \mathrm{~g}$ to $13.1 \mathrm{~g} / 100 \mathrm{~g}$. The blended flour $\mathrm{C}$ made of a mix of pearl millet, beans, peanut paste, tamarind, sugar and iodized salt had the highest content of lipid but the lowest content of calcium $(89.5 \mathrm{mg} / 100 \mathrm{~g})$. Indeed, the calcium content for other blended flours was at least $100 \mathrm{mg} / 100 \mathrm{~g}$ (99.7 to $108.3 \mathrm{mg} / 100 \mathrm{~g}$ ). For zinc content, the values are quite similar for the different flours: between 2.7 and $3.1 \mathrm{mg} / 100 \mathrm{~g}$. Iron content ranged from 8.5 $\mathrm{mg} / 100 \mathrm{~g}$ for flour $\mathrm{C}$ to $18.3 \mathrm{mg} / 100 \mathrm{~g}$ for flour A. Blended flour $\mathrm{C}$ had also the lowest content in Vitamins $\mathrm{A}, \mathrm{C}$ and $\mathrm{E}$.

Table 3 shows the nutrient distribution of flours, computed for $100 \mathrm{kcal}$. The protein content ranged from 2.7 to $3.1 \mathrm{~g} / 100 \mathrm{kcal}$. The content range per $100 \mathrm{kcal}$ for some critical vitamins and minerals were:

- calcium 19.7-24.7 mg,

- $\quad$ zinc $0.6-0.7 \mathrm{mg}$

- iron: $1.9-4.3 \mathrm{mg}$

- Vitamin A: 1.1-16.9 $\mu \mathrm{g}$ RE

- Vitamin C: 9.5-17.7 mg

\section{Amount of porridge eaten by children}

The amount of each porridge (made from each blended flour) eaten was assessed each time by a sample of 10 children aged 12-23 months.

The mean amount of porridge eaten ranged from $167 \mathrm{ml}$ (flour C) to $197 \mathrm{ml}$ (flour B). At least $70 \%$ of children aged $12-23$ months ate the total amount of $200 \mathrm{ml}$ given to them. (Table 4).

\section{Sensory evaluation and feasibility}

The visual aspect was accepted by $100 \%$ of mothers for each type of porridge. The same percentage accepted the aroma for all porridge. About taste, $100 \%$ accepted porridge made from blended flours A, B, D and E. Only $80 \%$ accepted the taste of the porridge made from blended flour $\mathrm{C}$.

The time required to prepare a flour recipe was estimated at 2 hours per week for one child, and all women interviewed found it acceptable. Regarding production cost, the flours C, D, and E were less acceptable: only 50 to $60 \%$ of mothers found their cost acceptable. The ingredient which they found unaffordable was sugar. The amount of sugar needed per week to make the flours cost about 5 euro cents.

The costs per week per child for flours A, B, C, D, E, were respectively 1.5, 1.6, 1.65, 1.6 and 1.75 euros. 


\section{Choice of suitable blended flours}

Based on the sensory evaluation and feasibility (workload and the production cost) for communities, the flours A and B were selected as the best suited for the infants and they met the criteria of energy density, sensory, and feasibility (cost and workload). These two flours were made from the same raw materials, pearl millet, beans and peanuts. Flour A was composed by adding crushed sumbala and iodized salt, while small fish powder and iodized salt was added for flour composition B.

\section{DISCUSSION}

All the five blended flours met the minimum recommended energy density for complementary food of $400 \mathrm{kcal} / 100 \mathrm{~g}$ [11]. The energy content of the flours was sufficient for complementary feeding of children aged 6-23 months, based on two meals per day in addition to breast milk. In fact, the minimum energy requirement for complementary food of $4 \mathrm{kcal}$ per $\mathrm{g}$ of flour according to the Codex Alimentarius was met. Regarding nutrient densities, we compared the results to WHO recommendations and IOM recommendations $[13,14]$ as standards. Protein contents exceeded international recommendations but not the tolerated value of $15 \%$ of total amount of energy coming from proteins [11].

The high protein content was due to the combination of peanut paste and beans with fish powder or sumbala added for some blended flours. These products have protein contents of $23.2 \mathrm{~g} / 100 \mathrm{~g}$ and $23.1 \mathrm{~g} / 100 \mathrm{~g}$ for peanut paste and bean and $47.3 \mathrm{~g} / 100 \mathrm{~g}$ and 36.5 $\mathrm{g} / 100 \mathrm{~g}$ for fish powder and sumbala, respectively.

The content of vitamin $\mathrm{C}$ was adequate. However, no blended flour contained enough micronutrients such as zinc, and vitamin A. Calcium density was also below recommended levels, particularly for blended flour $\mathrm{C}$. The difference between blended flour $\mathrm{C}$ and others about calcium content came from the use of monkey bread in blended flours A, B D and E. Monkey bread is the fruit of the baobab tree (Adansonia digitata). The baobab is a large African savannah tree resisting drought in the dry season. Its leaves are used as vegetables by the rural populations in Burkina Faso and the fruit is used to make beverages appreciated for the acidulated taste. The baobab fruit is a good source of minerals, namely, calcium (295 mg / $100 \mathrm{~g})$, potassium (1240 mg / $100 \mathrm{~g})$ and magnesium (90 mg / $100 \mathrm{~g})$ [15].

The lipid content varied from $8.8 \mathrm{~g} / 100 \mathrm{~g}$ to $13.1 \mathrm{~g} / 100 \mathrm{~g}$ depending on the blended flour. Peanut paste was the main lipid-providing product in the composition of different flours. According to the food composition table of Burkina-Faso [16], the peanut paste content of lipid is $50.9 \mathrm{~g} / 100 \mathrm{~g}$. Therefore, $50 \%$ of the peanut paste is composed of lipid. Using peanut paste could then help improve energy content of infant flour.

For iron content, the flours $\mathrm{A}, \mathrm{B}, \mathrm{D}$ and $\mathrm{E}$ almost met the WHO requirements for all ages (6 months to 23 months), but the iron content for blended flour $\mathrm{C}$ was lower. The difference could be explained by the presence of Sumbala in the composition of the other blended flour. Sumbala is a local food condiment made of African locust bean (Parkia 


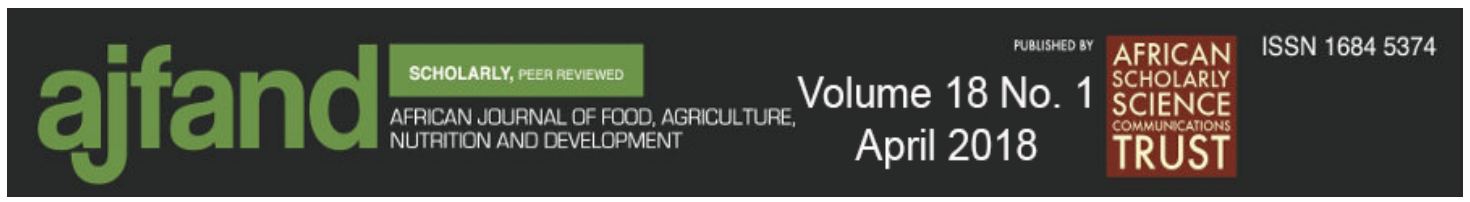

biglobosa) seed after a long process of baking and fermentation. The process is described in detail elsewhere [17]. Sumbala is rich in protein and iron. Its protein content ranges between 34 and $42 \mathrm{~g} / 100 \mathrm{~g}$ with a good amino-acid profile [18] and the iron content is $36.5 \mathrm{mg} / 100 \mathrm{~g}(16)$.

At the end of the analysis, two blended flours were found suitable regarding energy needs, micronutrients content, sensory test and feasibility (cost and workload needed). Both selected blended flours contained the same raw ingredients, pearl millet, beans and peanuts, which were locally available in all seasons and were also affordable. In addition, one of the two recipes used a local food condiment, sumbala, and the other fish powder. These ingredients were also available and affordable. The two flours can be recommended to mothers, to be prepared alternately in order to diversify the protein source for the children.

For all flour recipes, different mixtures of cereals and legumes were used, because it was demonstrated that they are complementary to cover many essential amino acids [19].

For each of the porridges prepared from the different flours, at least $70 \%$ of the children consumed $200 \mathrm{ml}$ and $80 \% 150 \mathrm{ml}$. These thresholds of $150 \mathrm{ml}$ and $200 \mathrm{ml}$ were chosen, taking into account the gastric capacity of the children (30 g/ kg of weight) and the mean weight of the 6-24 months children ranged between $6 \mathrm{~kg}$ and $12 \mathrm{~kg}$ [9]. A high proportion of children have consumed a volume of porridge close to their gastric capacity without being forced to do it, showing that the porridges were well accepted.

All mothers liked the visual appearance, taste and aroma of the porridges except for that of flour $\mathrm{C}$ for which $20 \%$ of mothers did not like the taste and the aroma. The reason evoked by these mothers was the too acid taste due to the tamarind.

With regard to cost, the feasibility was not good for the flour recipes that contained sugar. Usually, the ingredients used for the flour recipes were produced by families. Only sugar had to be bought and therefore became a luxurious, unaffordable ingredient. Thus, it is not so much the cost of the blended flour that is problematic but rather the need to buy some products such as sugar instead of taking them from the family crops.

The time spent ( 2 hours per week) for the preparation of the different flours was well accepted by the mothers. Rural mothers are busy with multiple tasks throughout a day and it is important that the child's meal does not take up all of their time. Otherwise, the proposed recipes will be abandoned. Two of the five flour recipes were both nutritionally adequate and economically accessible for mothers. However, there is a constraint in diversity with only two recipes. So, mothers should be advised to diversify their child's diet by giving other foods in addition to the porridges made of the two flour recipes.

Some improvements for the flours processing were provided, like soaking and toasting. In fact, pulses and legumes are known to contain anti-nutrient factors like phytate, leptin and trypsin. Phytate forms insoluble complexes with a range of nutrients and thereby inhibits the absorption of proteins and minerals, in particular iron, zinc, and calcium $[11,19]$. Heating reduces the content of some anti-nutrient factors like leptins and trypsin, 


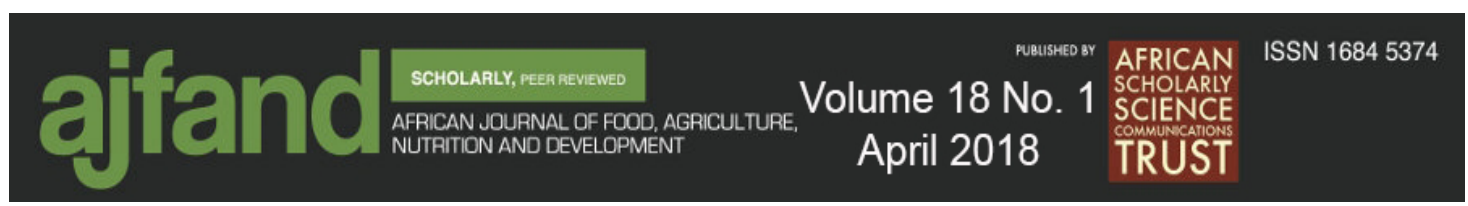

and soaking and fermentation reduce phytate content. Moreover, toasting enhances the flavor and the taste of the food through dextrinization of starch, reduces the food bulkiness and improves its digestibility. Toasting contributes to the reduction of microorganisms and enzyme activity and destroys insects [11,19].

\section{CONCLUSION}

To conclude, local complementary foods in this study were adequate for energy density with the advantage of low cost, good cultural and organoleptic acceptability. However, children eating these foods should receive additional sources of micronutrients. These sources may be fruits and vegetables but they are hardly eaten in the rural settings of Burkina Faso, even if they are produced. Therefore, promotion of fruit and vegetable consumption should be an important part of community-based programs in fighting malnutrition. Current strategies to improve micronutrients intake of infants and young children are fortification of cereals and supplementation of micronutrients [20]. The latter strategy now seems feasible with WHO recommendations to use multiple micronutrients powder for home food fortification, although large-scale feasibility and effectiveness needs more research [11].

\section{ACKNOWLEDGEMENTS}

The research team is thankful to the Red-Cross of Belgium for funding this work. We are also grateful to Ildephonse Ngabonziza for providing technical support. 


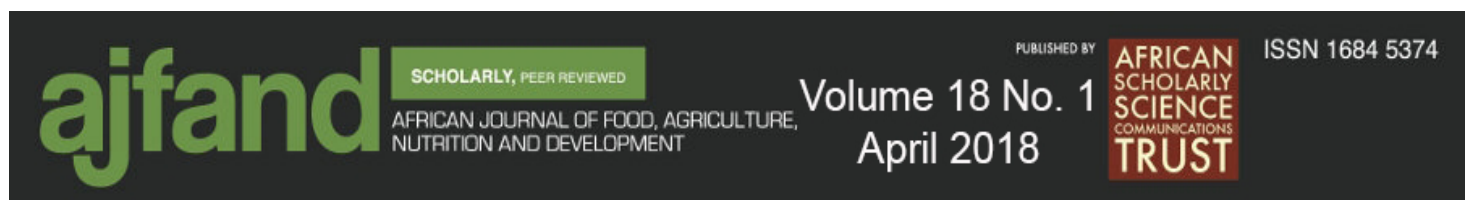

Table 1: Flour recipes

\begin{tabular}{|c|c|c|c|}
\hline & Ingredients & Quantity (g) & $\%$ \\
\hline \multirow{6}{*}{ Flour recipe A (2000 g) } & Pearl millet flour & 954 & 47.7 \\
\hline & Beans flour & 142 & 7.1 \\
\hline & Peanut paste & 468 & 23.4 \\
\hline & Crushed sumbala & 116 & 5.8 \\
\hline & Monkey bread powder & 300 & 15.0 \\
\hline & Iodized salt & 20 & 1.0 \\
\hline \multirow{6}{*}{ Flour recipe B (2000 g) } & Pearl millet flour & 996 & 49.8 \\
\hline & Beans flour & 148 & 7.4 \\
\hline & Peanut paste & 486 & 24.3 \\
\hline & Small fish powder & 50 & 2.5 \\
\hline & Monkey bread powder & 300 & 15.0 \\
\hline & Iodized salt & 20 & 1.0 \\
\hline \multirow{6}{*}{ Flour recipe C (2000 g) } & Pearl millet flour & 1094 & 54.8 \\
\hline & Beans flour & 164 & 8.2 \\
\hline & Peanut paste & 546 & 27.3 \\
\hline & Tamarind & 126 & 6.3 \\
\hline & Sugar & 50 & 2.5 \\
\hline & Iodized salt & 20 & 1.0 \\
\hline \multirow{6}{*}{ Flour recipe D (2000 g) } & Pearl millet flour & 986 & 49.3 \\
\hline & Beans flour & 148 & 7.4 \\
\hline & Peanut paste & 496 & 24.8 \\
\hline & Monkey bread powder & 300 & 15.0 \\
\hline & Sugar & 50 & 2.5 \\
\hline & Iodized salt & 20 & 1.0 \\
\hline \multirow{7}{*}{ Flour recipe E (2000 g) } & Pearl millet flour & 930 & 46.5 \\
\hline & Beans flour & 140 & 7 \\
\hline & Peanut paste & 458 & 22.9 \\
\hline & Crushed sumbala & 112 & 5.6 \\
\hline & Monkey bread powder & 290 & 14.5 \\
\hline & Sugar & 50 & 2.5 \\
\hline & Iodized salt & 20 & 1.0 \\
\hline
\end{tabular}




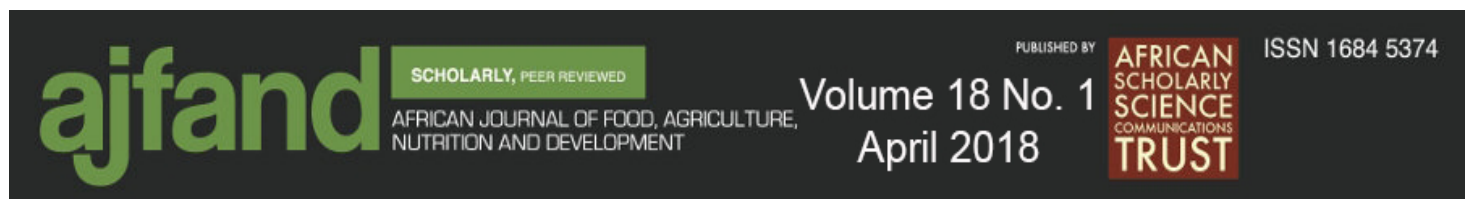

Table 2: Nutritional contents and energy density (per $100 \mathrm{~g}$ of flour)

\begin{tabular}{lccccc}
\hline Per 100g & Flour A & Flour B & Flour C & Flour D & Flour E \\
\hline Dry matter (g) & 92.4 & 92.8 & 93.8 & 92.6 & 93 \\
Energy (kcal) & 430 & 438 & 454 & 433 & 447 \\
Protein (g) & 11.5 & 14 & 14.2 & 13.4 & 13.8 \\
Lipids (g) & 8.8 & 9.9 & 13.1 & 9.6 & 11.5 \\
Sodium(mg) & 57.5 & 67.2 & 57.9 & 48.5 & 58 \\
Potassium(mg) & 268.6 & 266.8 & 205.4 & 262.1 & 243.3 \\
Calcium (mg) & 101.6 & 108.3 & 89.5 & 99.7 & 101.6 \\
Magnesium (mg) & 199.9 & 184.6 & 176.3 & 164.9 & 171.3 \\
Zinc (mg) & 2.9 & 2.7 & 3.3 & 2.9 & 3.1 \\
Iron (mg) & 18.3 & 10.5 & 8.5 & 12.4 & 9.7 \\
Vitamin A, $\mu \mathrm{gg} \mathrm{RE}$ & 31.4 & 16.9 & 4.9 & 73 & 63.7 \\
Vitamin C (mg) & 73.6 & 52 & 43.3 & 76.6 & 52 \\
Vitamin E (mg) & 0.31 & 0.27 & 0.15 & 0.28 & 0.38 \\
\hline
\end{tabular}

Table 3: Nutrients contents of flour recipes compared to WHO recommendations

\begin{tabular}{lcccccccc}
\hline $\begin{array}{c}\text { Nutrients per 100 } \\
\text { kcal }\end{array}$ & Flour A & Flour B & Flour C & Flour D & Flour E & $\begin{array}{c}\text { WHO 6- } \\
\mathbf{8 m}^{\mathbf{1}}\end{array}$ & $\begin{array}{c}\text { WHO 9- } \\
\mathbf{1 1 m}^{\mathbf{2}}\end{array}$ & $\begin{array}{c}\text { WHO } \\
\mathbf{1 2 - 2 3 \mathbf { m } ^ { 3 }}\end{array}$ \\
\hline Protein (g) & 2.7 & 3.2 & 3.1 & 3. & 3.1 & 0.7 & 0.7 & 0.7 \\
Sodium (mg) & 13.4 & 15.3 & 12.8 & 11.20 & 13.0 & $55^{*}$ & $55^{*}$ & $97.8^{*}$ \\
Potassium (mg) & 62.5 & 60.9 & 45.2 & 60.5 & 54.4 & $104.1^{*}$ & $104.1^{*}$ & $293.4^{*}$ \\
Calcium (mg) & 23.6 & 24.7 & 19.7 & 23.0 & 22.7 & 105 & 74 & 63 \\
Magnesium (mg) & 46.5 & 42.2 & 38.8 & 38.1 & 38.3 & $11.2^{*}$ & $11.2^{*}$ & $7.8^{*}$ \\
Zinc (mg) & 0.7 & 0.6 & 0.7 & 0.7 & 0.7 & 1.6 & 1.1 & 0.6 \\
Iron (mg) & 4.3 & 2.4 & 1.9 & 2.9 & 2.2 & 4.5 & 3 & 1.1 \\
Vitamin A, $\mu \mathrm{g}$ RE & 7.3 & 3.9 & 1.1 & 16.9 & 14.3 & 31 & 30 & 23 \\
Vitamin C & 17.1 & 11.9 & 9.5 & 17.7 & 11.6 & 1.5 & 1.7 & 1.5 \\
\hline Vitamin E (mg) & 0.07 & 0.06 & 0.03 & 0.06 & 0.09 & $0.89^{*}$ & $0.89^{*}$ & $0.59^{*}$ \\
\hline
\end{tabular}

*Recommended Nutrients Intakes (RNI) for Institute of Medicine (IOM)

1: children aged 6-8 months; 2: children aged 9 to 11 months; 3: children aged 12 to 23 months 


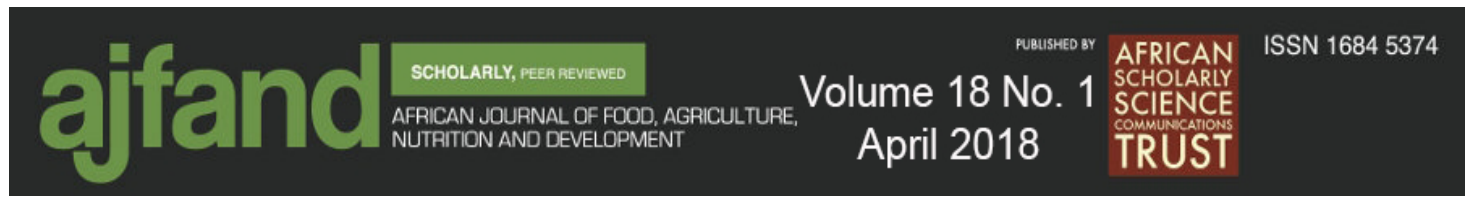

Table 4: Amount of porridge eaten, sensory and feasibility evaluation

\begin{tabular}{|c|c|c|c|c|c|}
\hline & $\begin{array}{l}\text { Flour } \\
\text { recipe A }\end{array}$ & $\begin{array}{l}\text { Flour } \\
\text { recipe B }\end{array}$ & $\begin{array}{l}\text { Flour } \\
\text { recipe C }\end{array}$ & $\begin{array}{l}\text { Flour } \\
\text { recipe D }\end{array}$ & $\begin{array}{l}\text { Flour } \\
\text { recipe E }\end{array}$ \\
\hline $\begin{array}{l}\text { Amount of porridge eaten } \\
\text { by children }(\mathrm{ml}) \text { : Mean } \\
+/ \text {-SD }\end{array}$ & $195+/-45$ & $197+/-50$ & $167+/-49$ & $190+/-52$ & $175+/-48$ \\
\hline $\begin{array}{l}\% \text { children eating the total } \\
\text { amount of } 200 \mathrm{ml}(\mathrm{N}=10)\end{array}$ & 80 & 80 & 70 & 80 & 70 \\
\hline $\begin{array}{l}\% \text { children eating at least } \\
150 \mathrm{ml}(\mathrm{N}=10)\end{array}$ & 100 & 90 & 80 & 90 & 90 \\
\hline $\begin{array}{l}\% \text { mothers accepting the } \\
\text { visual aspect (color and } \\
\text { consistency) }(\mathrm{N}=10)\end{array}$ & 100 & 100 & 100 & 100 & 100 \\
\hline $\begin{array}{l}\% \text { mothers accepting the } \\
\text { taste and aroma }(\mathrm{N}=10)\end{array}$ & 100 & 100 & 80 & 100 & 100 \\
\hline $\begin{array}{l}\% \text { mothers accepting the } \\
\text { workload involved (time } \\
\text { needed) }(\mathrm{N}=10)\end{array}$ & 100 & 100 & 100 & 100 & 100 \\
\hline $\begin{array}{l}\% \text { mothers accepting the } \\
\text { production cost }(\mathrm{N}=10)\end{array}$ & 100 & 90 & 60 & 60 & 50 \\
\hline
\end{tabular}




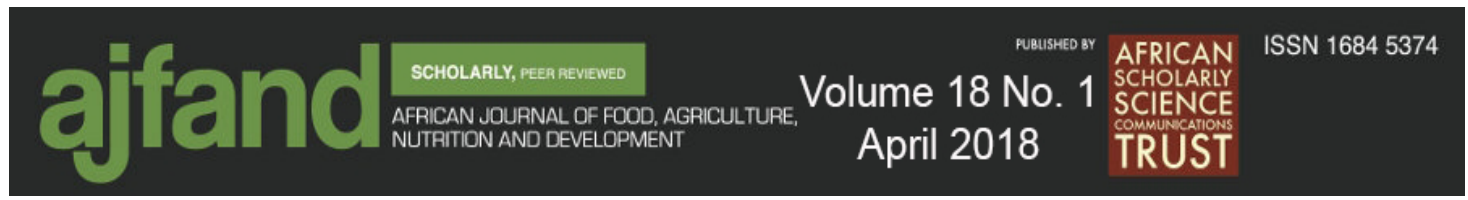

\section{REFERENCES}

1. United Nations Children's Fund, Organization WH, The World Bank. UNICEF-WHO-World Bank Joint Child Malnutrition Estimates. (UNICEF, New York; WHO, Geneva; The World Bank, Washington, DC; 2012).

2. Bhutta ZA and RA Salam Global nutrition epidemiology and trends. Ann. Nutr. Metab. 2012;61 (Suppl 1):19-27.

3. Bailey RL, West KP and RE Black The epidemiology of global micronutrient deficiencies. Ann. Nutr. Metab. 2015;66 (Suppl 2):22-33.

4. Müller $\mathbf{O}$ and $\mathbf{M}$ Krawinkel Malnutrition and health in developing countries. Can. Med .Assoc. J. 2005;173(3):279-86.

5. Bain LE, Awah PK, Geraldine N, Kindong NP, Sigal Y, Bernard N and AT Tanjeko Malnutrition in Sub-Saharan Africa: burden, causes and prospects. Pan. Afr. Med. J. 2013;15:120.

6. Faber M, Laubscher R, and $\mathbf{C}$ Berti Poor dietary diversity and low nutrient density of the complementary diet for 6- to 24-month-old children in urban and rural KwaZulu-Natal, South Africa. Matern. Child. Nutr. 2016;12(3):528-45.

7. Sawadogo SP, Yves M-P, Claire M-R, Alain B, Alfred TS, Serge T and F Delpeuch Late introduction and poor diversity were the main weaknesses of complementary foods in a cohort study in rural Burkina Faso. Nutrition 2010;26 (7-8):746-52.

8. Mamiro PS, Kolsteren P, Roberfroid D, Tatala S, Opsomer AS and JH Van Camp Feeding practices and factors contributing to wasting, stunting, and irondeficiency anaemia among 3-23-month old children in Kilosa district, rural Tanzania. J. Health. Popul. Nutr. 2005;23(3):222-30.

9. Dewey K Guiding principles for complementary feeding of the breastfed child. US11 [Internet]. Accessed July 26 2016; Available on:

http://iris.paho.org/xmlui/handle/123456789/752.

10. Centre d'Etude, de Formation et de Conseil, en Développement (CEFCOD). Situation de réference des principales filières agricoles au Burkina-Faso. Ministère de l'Agriculture et de la Sécurité Alimentaire du Burkina-Faso, Ouagadougou. 2003:200- 8.

11. Codex Alimentarius. Guidelines on formulated complementary foods for older infants and young children. 1991 p. 1-10. Report No.: CAC/GL 8-1991.

12. AOAC. Official methods of analysis of AOAC International. Gaithersburg, Md, USA, and Washington DC. 2005: 69-88. 


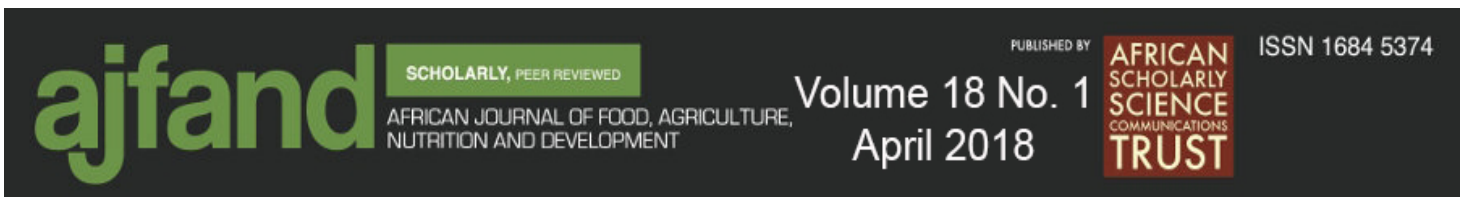

13. Lutter CK and JA Rivera. Nutritional Status of Infants and Young Children and Characteristics of Their Diets. J. Nutr. 2003;133(9):2941S-2949S.

14. Golden MH Proposed recommended nutrient densities for moderately malnourished children. Food. Nutr. Bull. 2009;30(3 suppl3):S267-S342.

15. Osman MA Chemical and nutrient analysis of baobab (Adansonia digitata) fruit and seed protein solubility. Plant. Foods Hum. Nutr. 2004;59(1):29-33.

16. Ministère de la Santé-Burkina. Edition et vulgarisation d'une table de composition des aliments couramment consommés au Burkina-Faso [Internet]. Accessed June 15 2016. Available on:

http://www.burkinadoc.milecole.org/Pieces_Jointes/PDFs/Agriculture durable /Alimentation/Tables_composition_nutritionnelle.pdf

17. Ouédraogo HZ, Traoré T, Zèba A, Tiemtoré S, Dramaix-Wilmet $\mathbf{M}$, Hennart $P$ and $P$ Donnen Development of an improved local-ingredient-based complementary food and technology transfer to rural housewives. Food. Nutr. Bull. 2009;30(2):153-60.

18. Ijarotimi OS and OO Keshinro Comparison between the amino acid, fatty acid, mineral and nutritional quality of raw, germinated and fermented African locust bean (Parkia biglobosa) flour. Acta Sci. Pol. Technol. Aliment. 2012;11(2):151-65.

19. Michaelsen KF, Hoppe C, Roos N, Kaestel P, Stougaard M, Lauritzen L, Mølgaard C, Girma $\mathbf{T}$ and $\mathbf{H}$ Friis Choice of foods and ingredients for moderately malnourished children 6 months to 5 years of age. Food. Nutr. Bull. 2009;30(3 Suppl):S343-404.

20. Krebs NF Food Based Complementary Feeding Strategies for Breastfed Infants: What's the Evidence that it Matters? Nutr. Today 2014;49(6):271-7. 